\title{
Influence of Building Heights and Nature of Rooftop Views on Propagation Loss Prediction for Tropical Environment in Ondo State, Nigeria
}

\author{
P. Akinyemi \\ Department of Physics \\ Adeyemi College of Education \\ Ondo State, Nigeria
}

\author{
O. O. Adeoye-Oladapo \\ Department of Physics \\ Adeyemi College of Education \\ Ondo State, Nigeria
}

\author{
O. T. Kolebaje \\ Department of Physics \\ Adeyemi College of Education \\ Ondo State, Nigeria
}

\begin{abstract}
In One of the underlying difficulties with the application of a predicting path loss model for any environment is that no two areas have the same building composition. It is therefore intractable to formulate the exact path loss model for all location. In order to overcome some of the problem stated above, parameters of certain propagation models must be finetuned with reference to target environment. In this study, the ITU-R 526 adopted Walfisch- Bertoni (W/B) path loss model is optimized base on the experimental campaign over some selected locations in Western part of Nigeria. Afterwards, the multiple diffraction loss component of the W/B model was modified to incorporate effects of building height variation $\Delta H_{b}$. In addition to variations in buildings height, the effect of top view of buildings on the diffraction of roof top fields down to street level were estimated between 1.61 $\mathrm{dB}$ and 5.32. The optimized model will be useful for the new breed technologies especially the advanced long term evolution in Nigeria.
\end{abstract}

\section{Keywords}

Pathloss, Walfisch-Bertoni model, Western Nigeria and optimized model.

\section{INTRODUCTION}

The introduction of cellular networks has imposed the need to predict radio path loss in all environments between elevated antenna and mobile street level [2]. Response to this need has been the development of models to describe the propagation in space $[1,3,7]$. In literature, series of propagation models were published because descriptions of terrain and land-use information can vary widely from location to location $[6,3]$. To account for the variations in building heights in the studied locations, parameters of certain propagation models must be optimized with reference to target environment [7, 4]. Outdoor radio wireless communication is ruled by reflection, diffraction, multipath from natural and man-made objects obstructing the propagation channels $[8,5]$. The arrival of the same signal from different paths and times and its combination at the receiver causes the signal to fade. This phenomenon is referred to as multipath fading and is a direct result of multipath propagation. Specifically, it has been reported in academic literature that the propagation models applied to microcells mobile systems have built-in-error generally of the order of 7-10 dB standard deviation [9].

This study present a theoretical model which account for the effect of building heights variation to make a site-specific prediction of the path loss averaged over sectors live signals transmission on macro-cellular service provider in an outdoor propagation in the western part of Nigeria.

\section{MEASUREMENT CAMPAIGN}

A site verification exercise was done using testing tool (Ericsson k800i mobile station) running on the software mode, calls were initiated at each test point until it established and the signal strength information sent over the air interface between the base station and the mobile station.. The field test were conducted in Ondo State, Nigeria, with two different operators namely A and B respectively. Site where one of the measurements are taken in Ondo State are depicted in Figure 1. Eight BS cell sites were randomly selected in the locations of study and calls were initiated at each test point until it is established and the signal strength information sent over the air interface between the base and the mobile station. These sites consist of building with varying heights. For every site, received signal strength were measured at a reference distance of $100 \mathrm{~m}$ from the base station and at subsequent interval of $100 \mathrm{~m}$. The environmental parameters of the studied locations is presented in Table 1. All measurements were taken in the mobile active mode and in three sectors of each base station. This was to ensure that the mobile phone was in constant touch with the base station. The obtained values from field measurements are then compared with those calculated using the existing models. The essence of this is to investigate the degree of consistence of these existing models with field measurements. Map showing one of the Investigated Urban Environments is depicted in Figure 2.

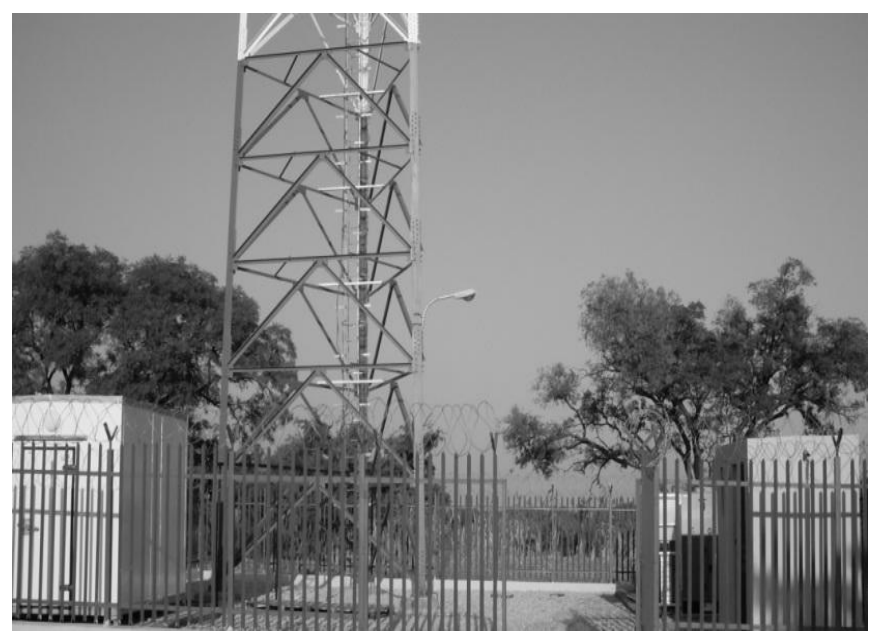

Figure 1: Site where one of the measurements are taken in Ondo State 


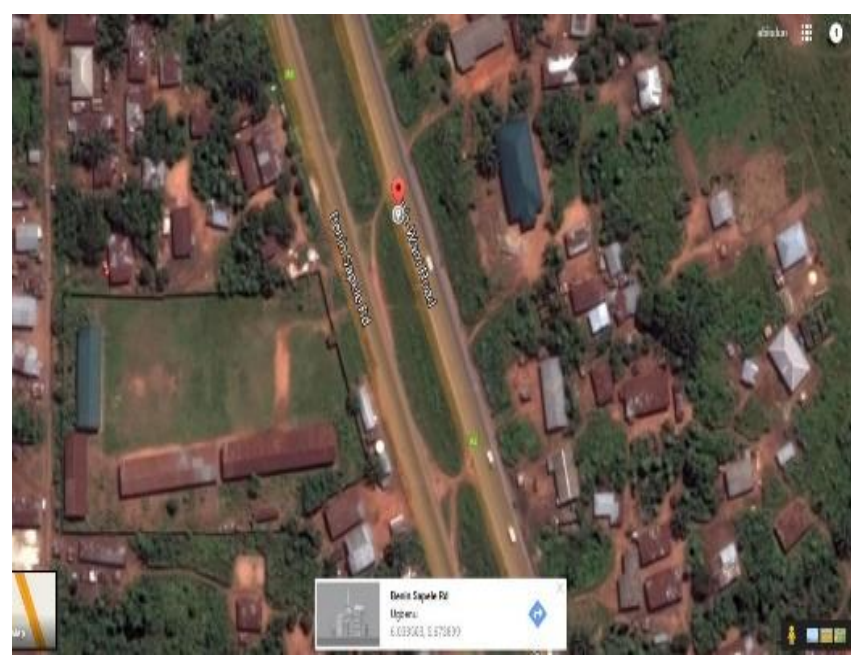

Fig. 2: Map showing one of the Investigated Urban Environments
Table 1: Base Station Parameter

\begin{tabular}{|l|l|l|}
\hline Parameters station & $40 \mathrm{~dB}$ & $40 \mathrm{Db}$ \\
\hline $\begin{array}{l}\text { Oase for } \\
\text { transmitter power }\end{array}$ & $\begin{array}{l}\text { Values } \\
\text { Operator B }\end{array}$ \\
\hline $\begin{array}{l}\text { Base station antenna } \\
\text { height }\end{array}$ & $40 \mathrm{~m}$ & $42 \mathrm{~m}$ \\
\hline Mobile antenna height & $1.2 \mathrm{~m}$ & $1.5 \mathrm{~m}$ \\
\hline $\begin{array}{l}\text { Transmitter antenna } \\
\text { gain }\end{array}$ & $17.5 \mathrm{~dB}$ & $17.5 \mathrm{~dB}$ \\
\hline Frequency & $900 \mathrm{MHz}$ & $1800 \mathrm{MHz}$ \\
\hline Feeder loss & $2.52 \mathrm{~dB}$ & $2.58 \mathrm{~dB}$ \\
\hline Duplexer loss & $4.5 \mathrm{~dB}$ & $4.75 \mathrm{~dB}$ \\
\hline
\end{tabular}

\section{THE WALFISCH-BERTONI MODEL}

Walfisch-Bertoni (W/B) modeled path loss to three elements: Free space loss, $\mathrm{P}_{\mathrm{GO}}$; reduction in the field at the rooftop just before the mobile due to propagation past previous buildings, $\mathrm{P}_{\mathrm{G} 1}$ and diffraction of the rooftop field down to the mobile (add ray power to get the small area average), $\mathrm{P}_{\mathrm{G} 2}$.

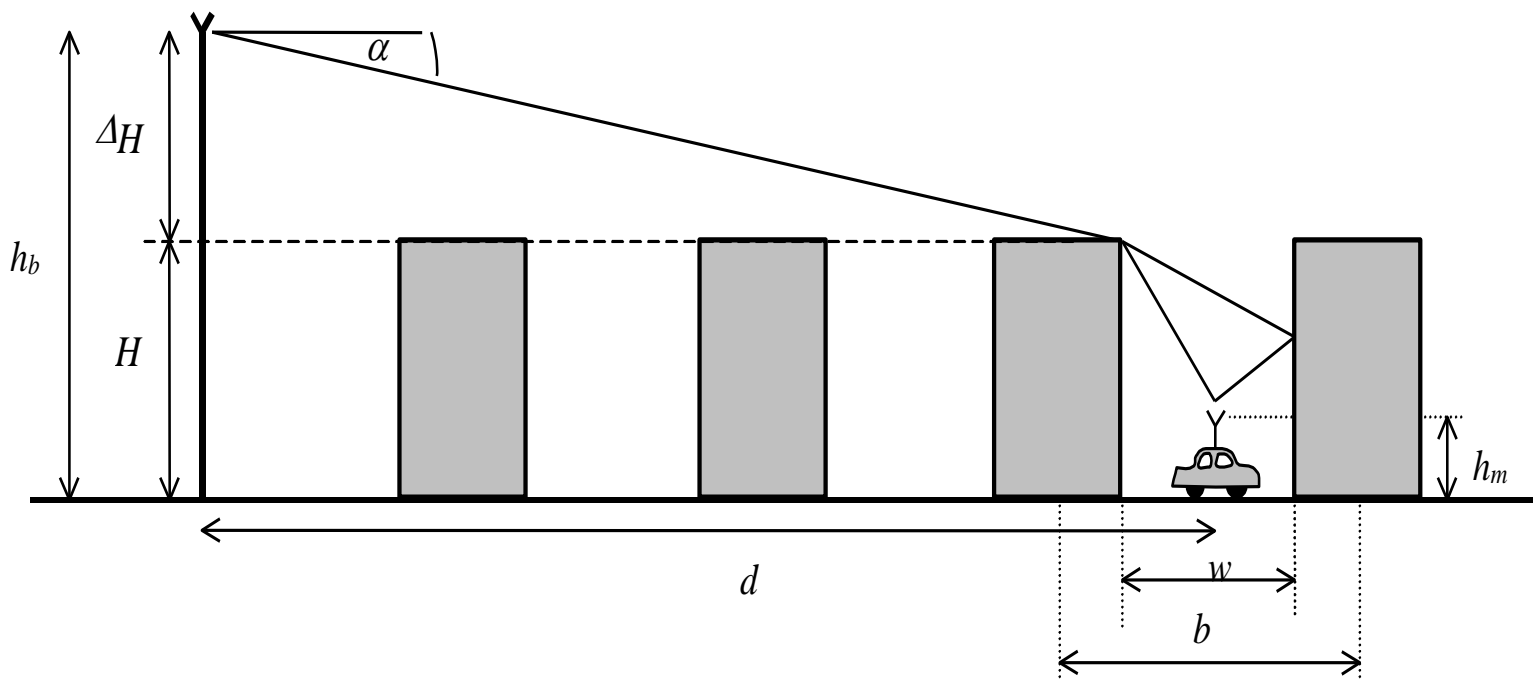

Figure 3: propagation geometry for Walfisch-Bertoni model

Total Path Loss, PG $=\left(P_{G O}\right)\left(P G_{1}\right)\left(P G_{2}\right)$

(1) Free space path loss is given as $[8,10]$

$P_{G O}=\left(\frac{\lambda}{4 \pi r}\right)^{2}$

Path loss as a result of multi-screen loss $\left(\mathrm{PG}_{1}\right)$ is given as $[7,8]$

$P G_{1}=P L_{\text {rooftops }}=$

$0.01\left(\frac{h_{T}-H_{B}}{0.03 R}\right)^{1.8}\left(\frac{d}{\lambda}\right)^{0.9}$

(3) Path loss as result of Diffraction and Reflection of propagated Signal form Rooftop down to the Street $\left(P G_{2}\right)$ is given as $[7,8]$

$$
\rho_{G 2}=\frac{1}{2 \pi \mathrm{K} \rho_{1}}\left[\frac{1}{\left|\theta_{2}\right|}-\frac{1}{2 \pi-\left|\theta_{1}\right|}\right]^{2} \approx \frac{1}{\kappa \pi \rho_{1} \theta_{1}{ }^{2}}
$$

Substituting Equations (2), (3) and (4) into Equation (1)

$P G=$

$\left(\frac{\lambda}{4 \pi r}\right)^{2} 0.01\left(\frac{h_{T}-H_{B}}{0.03 R}\right)^{1.8}\left(\frac{d}{\lambda}\right)^{0.9} \frac{\lambda \rho_{1}}{2 \pi^{2}\left(H_{b}-h_{m}\right)}$ 
Equation (5) can be expressed in decibels as:

$P G=89.5-10 \log \left[\frac{\rho_{1} d^{0.9}}{\left(H_{B}-h_{m}\right)^{2}}\right]+$

$21 \log f M-18 \log h T-H B+38 \log R K$

where,

$f_{M}=$ Frequency in $\mathrm{MHz} ; h_{T}=$ Antenna height in meters;

$H_{B}=$ Building height in meters

$h_{m}$ : Mobile height in meters.

\section{MODEL COMPARISM}

Among lots of propagation models: Hata, S U I, COST-231, Free Space and W/B models were suggested as good solutions for macro cellular signal in the studied locations because they are the most used propagation model in literature [7, 8]. From the results presented in Table 2 and 3 , the data obtained from the measurement are closer to the Walfisch-Bertoni model with RMSE value between 9.29-13.16 and far from FSPL with RMSE value between 32.67-47.44 for operator A and B. Based on the closest agreement with measurement data, the Walfisch-Bertoni is selected as the best model for signals prediction in Ondo State, Nigeria.

\subsection{W-B Model Optimization}

The influence of variations in building height from row to row is investigated by simulating random height variations and computing the resulting signal at the mobile for many such variations. In the studied locations, the buildings were assigned different heights that were uniformly distributed between $\left\langle H_{b}\right\rangle \pm \Delta H_{b}$, where $\left\langle H_{b}\right\rangle$ is the height of building and $\Delta \mathrm{H}_{\mathrm{b}}$ is the maximum height deviation. Therefore, the multiple diffraction loss components of the W/B model will be modified to include in building height, $\Delta H_{b}$ as thus; $P G_{1 \text { (New) }}=P L_{\text {rooftops (New) }}=0.01\left(\frac{h_{T}-\left(H_{B} \pm \Delta H_{B}\right)}{0.03 R}\right)^{1.8}\left(\frac{d}{\lambda}\right)^{0.9}$

Combining equation (2), (4) and (7), the optimized W/B pathloss model becomes:

$$
\begin{aligned}
& P L_{T(\text { New })}=89.5-10 \log \left[\frac{\rho_{1}(d)^{0.9}}{\left(H_{B}-h_{m}\right)^{2}}\right]+ \\
& 21 \log f_{M}-18 \log \left(h_{T}-\left(H_{B} \pm \Delta H_{B}\right)\right)+ \\
& 38 \log R_{k}
\end{aligned}
$$

In order to obtain an accurate estimate of building heights, for each configuration, building height variations, $\Delta \mathrm{H}_{\mathrm{b}}$, between $1.61 \mathrm{~dB}$ and 5.32. were simulated. The simulations were performed on 350 buildings of various heights measured with aid of clinometers in the studied locations. Also, the RMSE of the optimized W/B path loss model of the studied locations were calculated using equation ( 8 ) and summarized in Table 2.-3

Table 2: RMSE comparison between known models for measurements data for Operator A

\begin{tabular}{|l|l|l|l|l|l|l|}
\hline $\begin{array}{l}\text { BS } \\
\text { site }\end{array}$ & $\begin{array}{l}\text { FSPL } \\
\text { mode } \\
1\end{array}$ & $\begin{array}{l}\text { HAT } \\
\text { A } \\
\text { model }\end{array}$ & $\begin{array}{l}\text { COS } \\
\text { T 231 } \\
\text { mode } \\
1\end{array}$ & $\begin{array}{l}\text { SUI } \\
\text { mode } \\
1\end{array}$ & $\begin{array}{l}\text { W/B } \\
\text { mode } \\
1\end{array}$ & $\begin{array}{l}\text { Optimize } \\
\mathrm{d}\end{array}$ \\
$\begin{array}{l}\text { W/B } \\
\text { model }\end{array}$ \\
\hline $\begin{array}{l}\text { BS } \\
2\end{array}$ & 42.64 & 14.36 & 13.81 & 31.45 & 13.16 & 4.69 \\
\hline $\begin{array}{l}\text { BS } \\
3\end{array}$ & 41.19 & 13.28 & 13.62 & 24.60 & 9.29 & 5.59 \\
\hline $\begin{array}{l}\text { BS } \\
4\end{array}$ & 47.44 & 15.31 & 14.62 & 27.88 & 11.70 & 7.71 \\
\hline
\end{tabular}

Table 3: RMSE comparison between known models for measurements data for Operator B

\begin{tabular}{|l|l|l|l|l|l|l|}
\hline $\begin{array}{l}\text { BS } \\
\text { site }\end{array}$ & $\begin{array}{l}\text { FSPL } \\
\text { mode } \\
1\end{array}$ & $\begin{array}{l}\text { HAT } \\
\text { A } \\
\text { model }\end{array}$ & $\begin{array}{l}\text { COS } \\
\text { T 231 } \\
\text { mode } \\
1\end{array}$ & $\begin{array}{l}\text { SUI } \\
\text { mode } \\
1\end{array}$ & $\begin{array}{l}\text { W/B } \\
\text { mode } \\
1\end{array}$ & $\begin{array}{l}\text { Optimize } \\
\mathrm{d} \\
\text { W/B } \\
\text { model }\end{array}$ \\
\hline $\begin{array}{l}\text { BS } \\
1\end{array}$ & 34.54 & 13.29 & 14.76 & 21.69 & 11.43 & 6.17 \\
\hline $\begin{array}{l}\text { BS } \\
2\end{array}$ & 32.67 & 12.88 & 16.30 & 27.46 & 9.49 & 5.49 \\
\hline $\begin{array}{l}\text { BS } \\
3\end{array}$ & 38.31 & 11.70 & 14.45 & 24.11 & 8.82 & 4.71 \\
\hline $\begin{array}{l}\text { BS } \\
4\end{array}$ & 41.28 & 16.31 & 13.14 & 27.66 & 9.68 & 6.88 \\
\hline
\end{tabular}




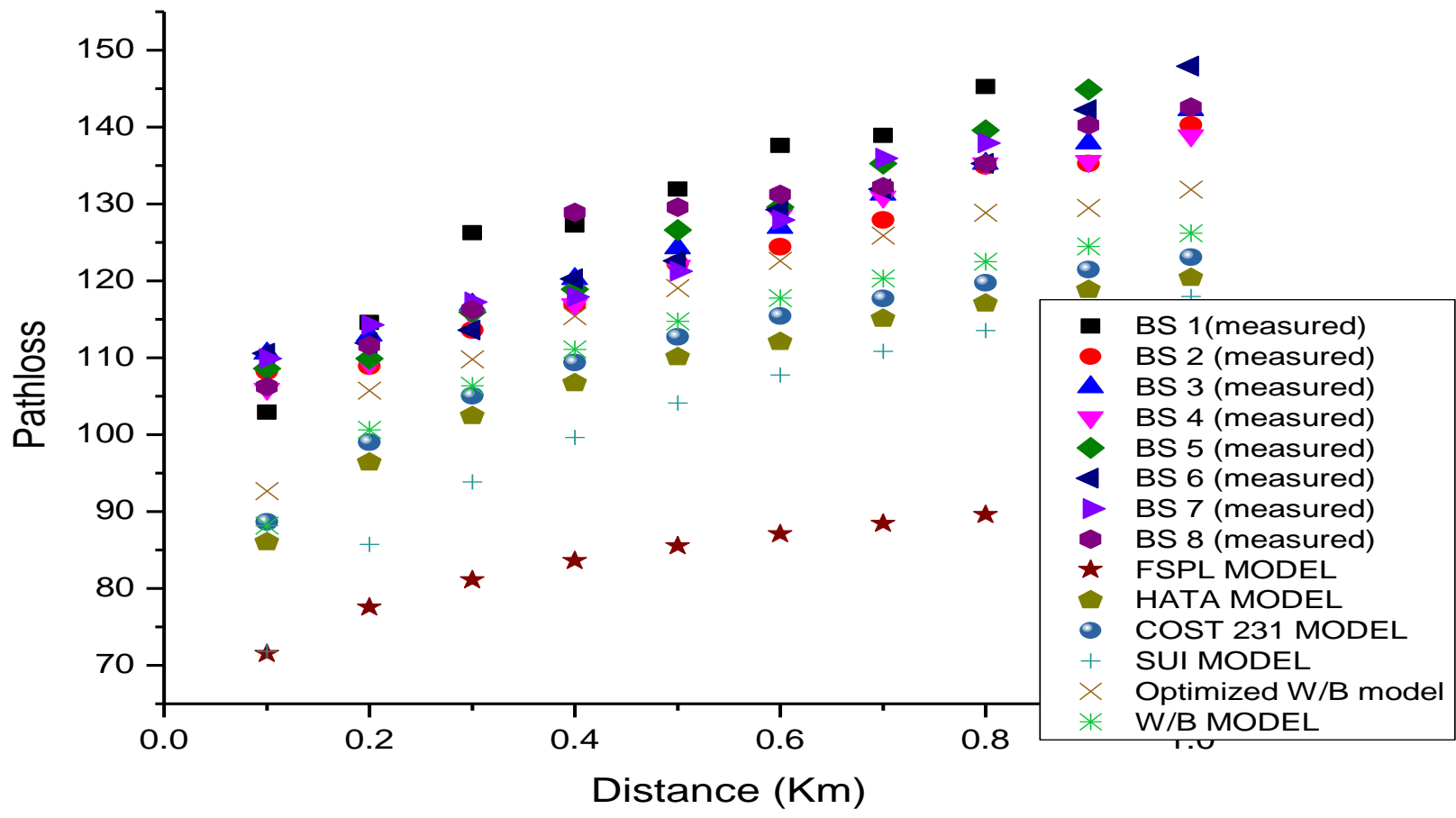

Fig. 4: Plots of the original W/B, optimized model W/B and measured path loss for operator A and B operating at 900 and $1800 \mathrm{MHz}$

\section{VARIABILITY DUE TO TOP VIEW}

In addition to variations in building height,. another source of variability considered was the effect of top view of buildings on the diffraction of roof top fields down to street level.

Several cases of building construction are depicted in top view as shown in Figure 5. For cases (A) and (C) in Figure 5, diffraction were considered as if it had occurred on an absorbing half screen using the diffraction factor in Equation (9) with $d / 2$ replaced by the horizontal distance $x$ from the equivalent half screen to the mobile. For building with a bsorbing insulation, the diffraction factor is given as =:

$$
\theta=\tan ^{-1}\left(, m \frac{\mathrm{h}_{\mathrm{B}}-\mathrm{h}_{\mathrm{m}}}{\mathrm{x}}\right)-\alpha
$$

For building with aluminized insulator or aluminized siding as shown in cases (B) and (D) in Figure 5, the diffraction factor is

$$
\text { given }
$$

$$
\begin{aligned}
& F_{c}=\frac{\sqrt{\lambda}}{4 \pi\left(x^{2}+\left(h_{B}-h_{m}\right)^{2}\right)^{\frac{1}{4}}}\left[\operatorname{cosec}\left(\frac{\pi+\theta}{2}\right)-\right. \\
& \left.\sec \left(\frac{\pi+\theta}{2}\right)\right] \quad \text { (10) }
\end{aligned}
$$

For average path loss model, diffraction down to street level is gives an intensity proportional to $2[F(d / 2)]^{2}$

The individual ray intensities relative to that used in the average path loss are given by

$1 / 2[F(x) / F(d / 2)]^{2}$ or by $1 / 2\left[F_{c}(x) / F(d / 2)\right]^{2}$

For these calculations $\lambda=1 / 4 \mathrm{~m}$ and $\alpha=0.9 \mathrm{rad}$ is assumed 


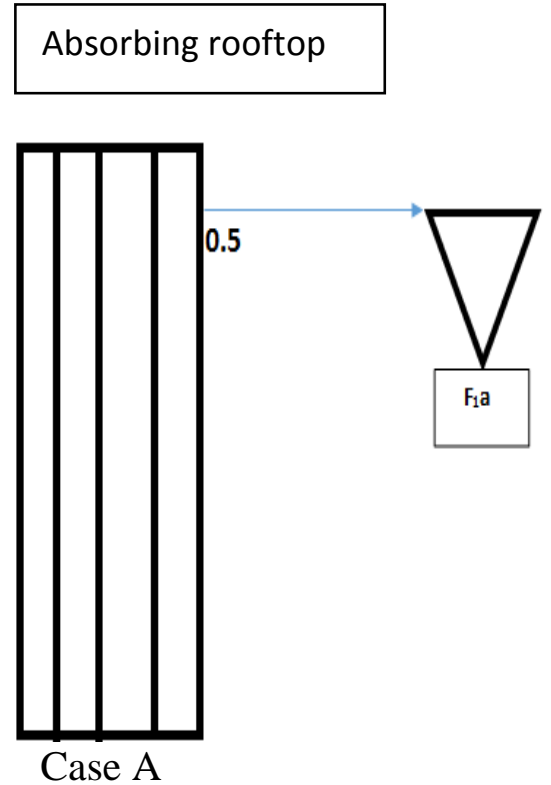

\section{Conducting rooftop}

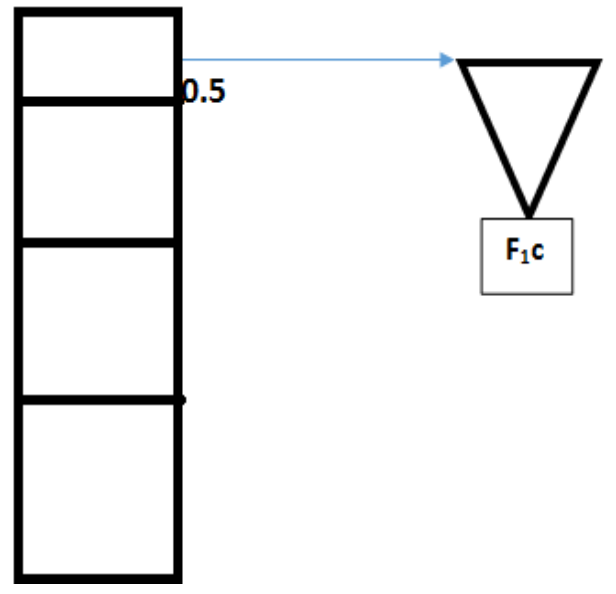

Case B

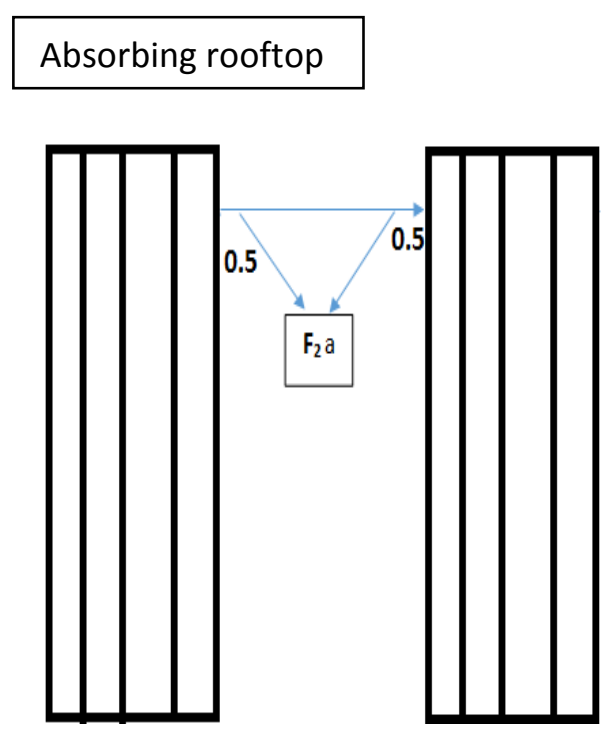

Case C

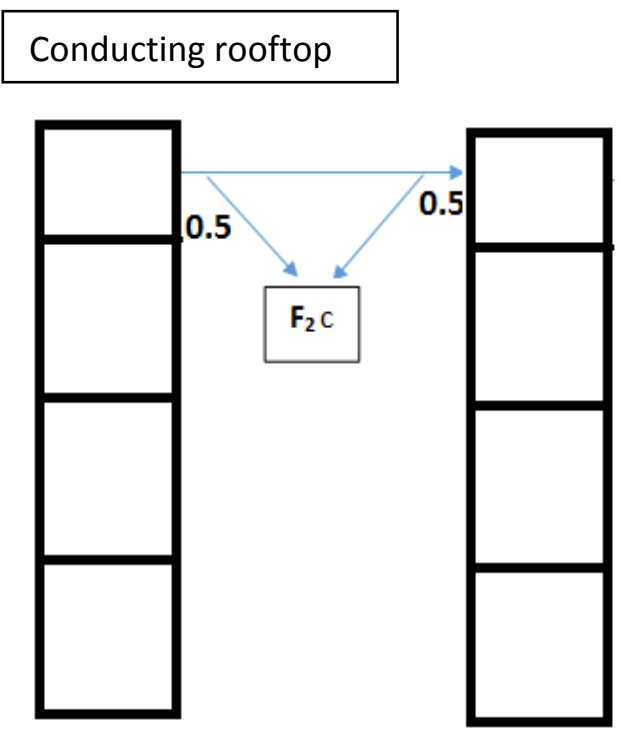

Case D

Figure 5: Top views of buildings

\section{CONCLUSION}

This paper presented a comparative study between measurement survey on live signal transmission of macrocellular service providers situated in Ondo, Nigeria. The result revealed that the optimized W/B model have better predicting accuracy when compared to the original W/B in the studied locations. It could be observed from Figure 4 and Table 2-3 that the optimized W/B model have better predicting accuracy when compared to the original W/B in the studied locations. Difference in RMSE values between the proposed and Walfisch-Bertoni model are ranged from $0 \mathrm{~dB}$ up to $3 \mathrm{~dB}$. Therefore, for all the studied macro cells, the introduction of building heights variation in the multiple diffraction loss components of the W/B model improved the model's prediction accuracy. Thus, the proposed optimized path loss models indicate better prediction accuracy in term of root mean square error when compared to the original
Walfisch Bertoni model. It was also observed that the nature of the rooftop (view of buildings) and its effect on diffraction of roof top fields down to street level will result in deviations sector averaged signals that range between $1.6 \mathrm{~dB}$ and 5.32

\section{ACKNOWLEDGEMENT}

This research work was sponsored by TETFund. Special thanks to Engr. Abiodun Oladoyin and Abiodun Isaac for sharing their pearls of wisdom during the course of the research

\section{REFERENCES}

[1] Devasirvatham, D. M., M. J. Krain,R and T. S. Rappaport (1990) "Radio propagation measurements at $850 \mathrm{MHz}$, $1.7 \mathrm{GHz}$, and $4.0 \mathrm{GHz}$ inside two dissimilar office buildings," Electronics Letters, Vol. 26, No. 7, 445-447. 
[2] Rappaport, T. S. and D. A. Hawbaker (1992) "Wide-band microwave propagation parameters using cellular and linear polarized antennas for indoor wireless channels," IEEE Trans. On Communications, Vol. 40, No. 2, 231242.

[3] Tarng, J. H., W. R. Chang, and B. J. Hsu (1997) "Three dimensional modeling of $900 \mathrm{MHz}$ and $2.44 \mathrm{GHz}$ radio propagation in corridors," IEEE Trans. Veh. Technol., Vol. 46, 519-526, 1997.

[4] Gibson, T. B. and D. C. Jenn (1999) "Prediction and measurements of wall intersection loss," IEEE Trans. Antennas Propagat., Vol. 47, 55-57.

[5]-Lafortune, J. F. and M. Lecours (1990) "Measurement and modeling of propagation losses in a building at 900 MHz," IEEE Trans. Veh. Technol., Vol. 39, 101-108.

[6] Akinyemi p., S.O Azi, J.S Ojo, C.I Abiodun ," Evaluatons for Suitable Propagation Model to Mobile Communications in South-South Nigeria Urban-Terrain", American Journal and Engineering Research (AJER), 2015
[7] Y. S. Meng, Y. H. Lee, and B. C. Ng (2009). Study of propagation loss prediction in forest environment. Progress in Electromagnetics Research B, Vol. 17, Pp. 117-133.

[8] Akinyemi P., Ojo J.S., Abiodun C. I. and Ojo O.L. Optimization of pathloss model for GSM network Applications in Delta State, Nigeria. $6^{\text {th }}$ National Annual Conference of the Nigeria Union of Radio Science, held at University of Ilorin, Ilorin, Kwara State, December 25, 2015, Nigeria

[9] Saunders, S.R. and Bonar F.R., (1994). Prediction of Mobile Radio Wave Propagation over Buildings Heights and Spacing. IEEE Transactions on Antennas and Propagation, Vol. 42, No. 2, Pp.137-144

[10] C.I. Abiodun, S.O. Azi, J.S Ojo and P. Akinyemi (2017). Assessment of path Loss Prediction Models for wireless propagation Channels at L-Band Frequency over different Macro-Cellular Environment of Ekiti State, Southwestern Nigeria. World Academy of Science, Engineering and Technology. International JOURNAL OF Electronics and communication Engineering Vol. 11, No. 10, Pp. 1103-1109 